\title{
Effects of Fertilizer Placement on Trace Gas Emissions from Nursery Container Production
}

\author{
S. Christopher Marble ${ }^{1}$ \\ Auburn University, Department of Horticulture, 101 Funchess Hall, Auburn, \\ Auburn, AL 36849
}

\author{
Stephen A. Prior ${ }^{2}$, G. Brett Runion ${ }^{3}$, and H. Allen Torbert ${ }^{4,8}$ \\ USDA-ARS National Soil Dynamics Laboratory, 411 S. Donahue Drive, \\ Auburn, AL 36832
}

Charles H. Gilliam ${ }^{5}$, Glenn B. Fain ${ }^{6}$, and Jeff L. Sibley ${ }^{5}$

Auburn University, Department of Horticulture, 101 Funchess Hall, Auburn, AL 36849

\section{Patricia R. Knight ${ }^{7}$ \\ Mississippi State Coastal Research and Extension Center, 1815 Popp's Ferry Road, Biloxi, MS 39532}

Additional index words. carbon dioxide, climate change, greenhouse gases, horticulture, methane, nitrous oxide

\begin{abstract}
Increased trace gas emissions of carbon dioxide $\left(\mathrm{CO}_{2}\right)$, methane $\left(\mathrm{CH}_{4}\right)$, and nitrous oxide $\left(\mathrm{N}_{2} \mathrm{O}\right)$ are widely believed to be a primary cause of global warming. Agriculture is a large contributor to these emissions; however, its role in climate change is unique in that it can act as a source of trace gas emissions or it can act as a major sink. Furthermore, agriculture can significantly reduce emissions through changes in production management practices. Much of the research on agriculture's role in mitigation of greenhouse gas (GHG) emissions has been conducted in row crops and pastures as well as forestry and animal production systems with little focus on contributions from specialty crop industries such as horticulture. Our objective was to determine efflux patterns of $\mathrm{CO}_{2}, \mathrm{CH}_{4}$, and $\mathrm{N}_{2} \mathrm{O}$ associated with three different fertilization methods (dibble, incorporated, and topdressed) commonly used in nursery container production. Weekly measurements indicated that $\mathrm{CO}_{2}$ fluxes were slightly lower when fertilizer was dibbled compared with the other two methods. Nitrous oxide fluxes were consistently highest when fertilizer was incorporated. Methane flux was generally low with few differences among treatments. Results from this study begin to provide data that can be used to implement mitigation strategies in container plant production, which will help growers adapt to possible emission regulations and benefit from future GHG mitigation or offset programs.
\end{abstract}

Over the past several decades global warming has received increased attention from the scientific community including possible impacts of increased temperature on the global environment. Anthropogenically enhanced climate change is still highly debatable; however,

Received for publication 2 Apr. 2012. Accepted for publication 1 June 2012

This work was supported by the USDA-ARS Floriculture and Nursery Research Initiative and the Horticulture Research Institute.

We thank Barry G. Dorman and Gary M. Foster for technical assistance.

${ }^{1}$ Graduate Research Assistant.

${ }^{2}$ Plant Physiologist.

${ }^{3}$ Plant Pathologist.

${ }^{4}$ Soil Scientist and Research Leader.

${ }^{5}$ Professor of Horticulture.

${ }^{6}$ Assisstant Professor of Horticulture.

${ }^{7}$ Head Extension/Research Professor.

${ }^{8}$ To whom reprint requests should be addressed; e-mail allen.torbert@ars.usda.gov.
2000). Agricultural production is the largest contributor of anthropogenic $\mathrm{CH}_{4}$ and $\mathrm{N}_{2} \mathrm{O}$ emissions accounting for $52 \%$ and $84 \%$, respectively, of annual anthropogenic global emissions (Smith et al., 2008). The major sources of $\mathrm{CH}_{4}$ production from agriculture include enteric fermentation in ruminant animals, flooded rice fields, biomass burning, and manure management and storage (Cole et al., 1997; Johnson et al., 1993; USDA, 2008). Nitrous oxide emissions are a direct result of increased use of synthetic fertilizers and production of legumes, resulting in $80 \%$ of the total $\mathrm{N}_{2} \mathrm{O}$ emissions in the United States (Mosier et al., 2003).

Agriculture production is unique compared with other industries in that it can act as a GHG source but can also act as a sink for GHG through changes in production management. Increased $\mathrm{C}$ storage through conservation or "no-till" has been shown to maintain or increase soil $\mathrm{C}$ levels and reduce fossil fuel use (Paustian et al., 1997; Reicosky et al., 1999; Smith et al., 1998). Methane emissions have been shown to be greatly reduced by adding feed supplementation to the diets of ruminant animals and by proper manure handling (Cole et al., 1997; Leng, 1991; Lin et al., 1994; Safley et al., 1992). Nitrous oxide emissions can be reduced by improving nitrogen $(\mathrm{N})$ use efficiency (Kroeze et al., 1999; Kroeze and Mosier, 2000). Proper N fertilization timing (Weier et al., 1993) and placement (Oenema et al., 2001; Youngdahl et al., 1986) have also been shown to successfully reduce total $\mathrm{N}$ loss.

Several best management practices have been developed for reducing emissions of $\mathrm{CO}_{2}$ (Paustian et al., 2000), $\mathrm{CH}_{4}$ (Mosier et al., 1998), and $\mathrm{N}_{2} \mathrm{O}$ (Snyder et al., 2007) from agricultural production. Other programs such as Greenhouse Gas Reduction through Agricultural Carbon Enhancement network (GRACEnet) have also been initiated by the USDA-ARS to focus on reducing GHG emissions by altering current agricultural production practices. Past research has focused predominantly on agronomic, forestry, and animal production systems with little attention given to specialty industries such as horticulture. The green industry (nursery, greenhouse, and sod production) is one of the fastest growing sectors in agriculture (Hall et al., 2005); however, almost no research has focused on the impacts of this industry on GHG emissions.

Providing best management options for reducing GHG would not only reduce the environmental impact of the industry, but could benefit growers financially. There are now government and industry programs that provide tax incentives and payments to encourage farmers to reduce emissions and provide $\mathrm{C}$ offsets by altering current production practices (Chicago Climate Exchange, 2009; Environmental Protection Agency, 2009; National Farmers Union, 2009; Schmidt, 2009). There is also speculation that agricultural GHG emissions could be "capped" or taxed in the future (Adams, 2009; Blanford and Josling, 2009; Moore and Bruggen, 2011). 
$\mathrm{CO}_{2}$ Trace Gas Efflux (plants and media)

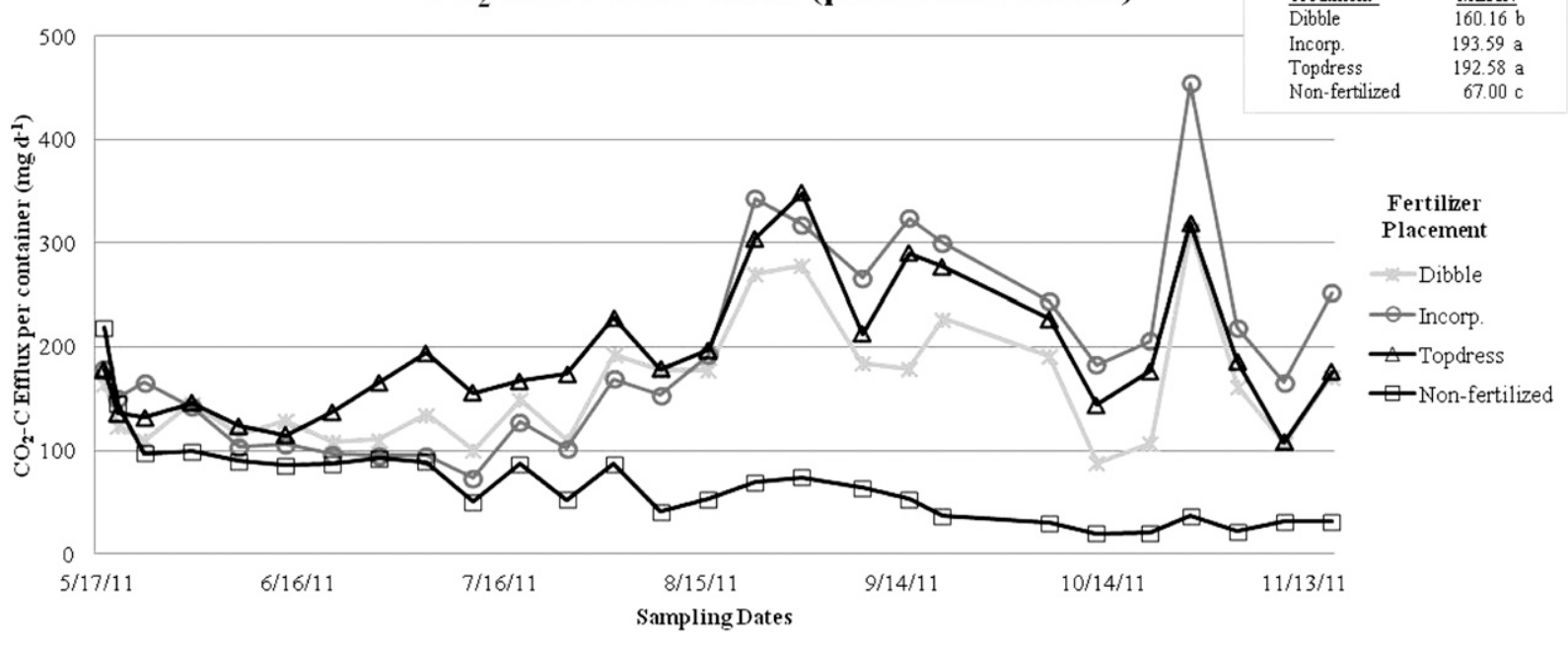

Fig. 1. $\mathrm{CO}_{2}-\mathrm{C}$ efflux $\left(\mathrm{mg} \cdot \mathrm{d}^{-1}\right)$ for gumpo azaleas grown with three different fertilizer placements for 6 months (17 May to 17 Nov. 2011). The inset shows average daily efflux (means followed by the same letter are not significantly different from each other, $P \leq 0.05$ ).

There is a need to develop mitigation strategies for nursery production practices to help growers adapt to possible future legislation and benefit from $\mathrm{C}$ trading or offset programs.

One method of GHG mitigation that has been previously investigated is fertilizer placement in agricultural soils [Breitenbeck and Bremner, 1986; Council for Agricultural Science and Technology (CAST), 2004; Engel et al., 2009; Hosen et al., 2000; Liu et al., 2006; Millar et al., 2010; Mosier et al., 1996; Prasertsak et al., 2002; Stefanson, 1976]. The placement of fertilizers into the soil and near the zone of active root uptake may reduce $\mathrm{N}$ loss from leaching and increase plant $\mathrm{N}$ use efficiency, which would reduce the amount of $\mathrm{N}$ that could be lost through $\mathrm{N}_{2} \mathrm{O}$ emissions (CAST, 2004). Concentrated N placement of urea fertilizer in agricultural soils using a band or nest placement has been shown to increase $\mathrm{N}_{2} \mathrm{O}$ production when compared with a broadcasted application, attributable in part to higher soil $\mathrm{N}$ accumulations (Engel et al., 2009). Breitenbeck and Bremner (1986) reported that after injection of anhydrous ammonia fertilizer, $\mathrm{N}_{2} \mathrm{O}$ production increased with injection depth, whereas in contrast, Hosen et al. (2000) and Stefanson (1976) reported that emission rate of $\mathrm{N}_{2} \mathrm{O}$ did not change with depth of fertilizer application.

Although less studied, fertilizer placement could also affect $\mathrm{CO}_{2}$ and $\mathrm{CH}_{4}$ emissions by impacting plant growth. In agricultural soils, $\mathrm{CO}_{2}$ is primarily produced from oxidation of soil organic materials by heterotrophic microorganisms and the respiration of plant roots, whereas $\mathrm{CH}_{4}$ is produced under anaerobic conditions by microbial decomposition of organic materials (Yamulki and Jarvis, 2002). Fertilizer placement has been shown to affect shoot and root growth of containergrown nursery crops (Altland et al., 2004), which could indirectly impact net GHG emissions because increased crop growth will sequester more $\mathrm{C}$ in growing biomass. In

Table 1. Cumulative trace gas $\left(\mathrm{CO}_{2}, \mathrm{CH}_{4}\right.$, and $\left.\mathrm{N}_{2} \mathrm{O}\right)$ efflux from container-grown woody nursery crops ${ }^{2}$ using three different fertilization placements.

\begin{tabular}{lccc}
\hline & \multicolumn{3}{c}{ Cumulative efflux } \\
\cline { 2 - 4 } Fertilizer placement ${ }^{\mathrm{y}}$ & $\mathrm{CO}_{2}-\mathrm{C}(\mathrm{mg})$ & $\mathrm{N}_{2} \mathrm{O}-\mathrm{N}(\mu \mathrm{g})$ & $\mathrm{CH}_{4}(\mu \mathrm{g})$ \\
\hline Dibble & $651.80 \mathrm{~b}^{\mathrm{x}}$ & $602.62 \mathrm{~b}$ & $-3.82 \mathrm{c}$ \\
Incorporated & $785.93 \mathrm{a}$ & $1883.84 \mathrm{a}$ & $21.70 \mathrm{bc}$ \\
Topdressed & $781.45 \mathrm{a}$ & $572.27 \mathrm{~b}$ & $56.16 \mathrm{ab}$ \\
Non-fertilized & $325.19 \mathrm{c}$ & $21.09 \mathrm{c}$ & $76.42 \mathrm{a}$ \\
\hline
\end{tabular}

${ }^{7}$ Containers measured contained white gumpo azaleas (Azalea $\times$ hybrida 'Gumpo White') potted into a pine bark:sand (6:1 v:v) media. Cumulative efflux was calculated using the trapezoid rule $(\mathrm{n}=7)$.

${ }^{\mathrm{y}}$ The same fertilizer rate $\left[25 \mathrm{~g}\right.$ of product (Polyon ${ }^{\circledR} 17-5-11$ ) per 3-L container] was used for all placement treatments with the exception of non-fertilized pots, which received no Polyon ${ }^{\circledR}$ fertilizer. Media in all treatments was amended with dolomitic limestone $\left(3.0 \mathrm{~kg} \cdot \mathrm{m}^{-3}\right)$, and Micromax ${ }^{\circledR}\left(0.9 \mathrm{~kg} \cdot \mathrm{m}^{-3}\right)$.

${ }^{x}$ Means were separated using Fisher's least significant difference test in the Proc Mixed procedure $(P=$ $0.05)$.

$\mathrm{CO}_{2}=$ carbon dioxide; $\mathrm{CH}_{4}=$ methane; $\mathrm{N}_{2} \mathrm{O}=$ nitrous oxide .

a study by Liu et al. (2006), deep N placement $\left(10\right.$ to $15 \mathrm{~cm}$ ) resulted in lower $\mathrm{N}_{2} \mathrm{O}$ emissions compared with shallow $\mathrm{N}$ placement $(0$ to $5 \mathrm{~cm}$ ), although $\mathrm{CO}_{2}$ and $\mathrm{CH}_{4}$ emissions were unaffected by $\mathrm{N}$ placement depth.

Due to a lack of a general conclusion regarding the affect of $\mathrm{N}$ placement on GHG emissions, Mosier et al. (1996) concluded that the diverse combinations of physical and biological factors, which control gas fluxes, are likely the cause of the conflicting results seen in previously published literature. Smith et al. (1997) also concluded that emission rates from different placements will likely vary from one system to another because of complex interactions of soil, crop, and environmental factors that must be taken into account. The same could be said for fertilizer type or formulation, which has also yielded conflicting results depending on the production system being evaluated (Snyder et al., 2009). Although fertilization placement has been shown to affect emission rates, individual production systems will likely have varying results and different mitigation strategies may need to be developed for different production systems. Previous work has focused on agronomic crops; however, it is important to also understand how fertilizer placement will affect emissions in specialty crop industries such as horticulture. Therefore, the objective of this study was to determine the effects of fertilizer placement on $\mathrm{CO}_{2}, \mathrm{CH}_{4}$, and $\mathrm{N}_{2} \mathrm{O}$ emissions from container production of a woody nursery crop.

\section{Materials and Methods}

This experiment was initiated at the Paterson Greenhouse Complex, Auburn University, AL. On 17 May 2011, Azalea $\times$ hybrid 'Gumpo White' (white gumpo azaleas) that were $\approx 15 \mathrm{~cm}$ in height with a 10 -cm canopy width were transplanted from 72 cell-pack liners $(2.5 \mathrm{~cm})$ into 3.8-L containers; enough transplants were obtained to ensure there were no differences in plant size among treatments at study initiation. Containers were filled with a pine bark:sand (6:1 v:v) media, which had been previously amended with $3.0 \mathrm{~kg} \cdot \mathrm{m}^{-3}$ of ground dolomitic limestone and $0.9 \mathrm{~kg} . \mathrm{m}^{-3}$ of Micromax ${ }^{\circledR}$ micronutrient (The Scotts Company, LLC, Marysville, OH). Polyon ${ }^{\circledR}$ (Harrell's LLC, Lakeland, FL) $17 \mathrm{~N}-2.2 \mathrm{P}-$ $4.2 \mathrm{~K}(17-5-11)$ controlled-release fertilizer (10 to 12 month) was applied at a potting at a rate of $25 \mathrm{~g}$ per container using the three different methods described by Altland et al. 


\section{$\mathrm{CO}_{2}$ Trace Gas Efflux (media only)}

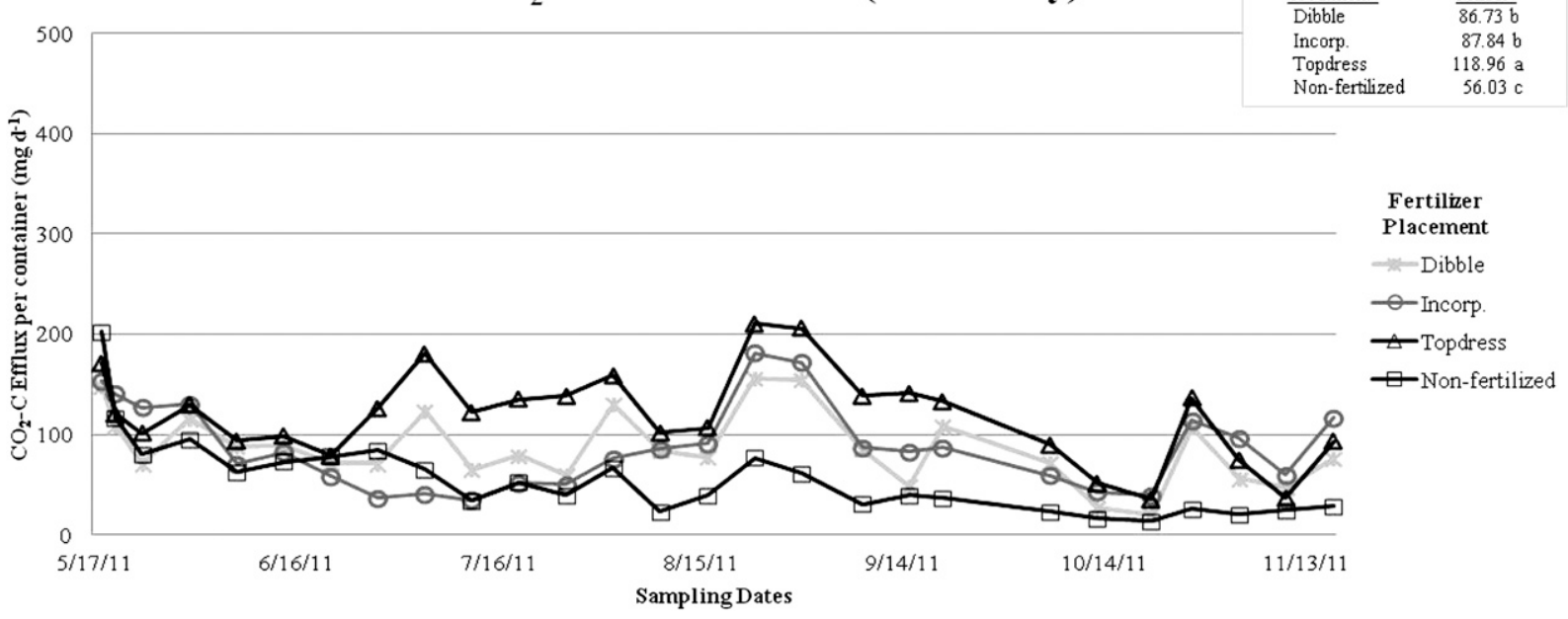

Fig. 2. $\mathrm{CO}_{2}$ - C efflux $\left(\mathrm{mg} \cdot \mathrm{d}^{-1}\right)$ from container media with three different fertilizer placements for 6 months (17 May to 17 Nov. 2011$)$. The inset shows average daily efflux (means followed by the same letter are not significantly different from each other, $P \leq 0.05$ ).

(2004): dibble, incorporation, and topdressing. Dibbled fertilizer was placed immediately beneath the rootball of azalea transplants ( $8 \mathrm{~cm}$ below the container media surface). Incorporated fertilizer was premixed into the pine bark media just before potting. Topdressed fertilizer was placed on the container surface immediately after potting. An additional treatment received only incorporated lime and Micromax ${ }^{\circledR}$ amendments with no other fertilization. The study used seven replicates for each fertilizer placement treatment with plants and three additional replications per treatment with media only. After potting, all containers with plants were placed in a retractable roof shade structure in a randomized complete block design and received daily overhead irrigation $(1.3 \mathrm{~cm})$. Media-only containers were placed adjacent to containers with plants in the retractable roof shade structure in a similar manner. At the time of study initiation, an additional 10 gumpo azaleas, similar in size to those used in the study, were used to determine initial plant biomass. Plant growth index [(plant height + width $1+$ width2)/3] was measured, shoots were cut at the media surface, media was removed from roots, and shoots and roots were dried for $\approx 72 \mathrm{~h}$ at $55{ }^{\circ} \mathrm{C}$ in a forced-air oven before weighing. Roots and shoots were then ground separately to pass through a $0.2-\mathrm{mm}$ mesh sieve. Concentrations of $\mathrm{C}$ and $\mathrm{N}$ were determined using a LECO 600-CHN analyzer (LECO Corp., St. Joseph, MI).

Trace gases emitted from the containers were sampled in situ weekly for 6 months (17 May to 17 Nov.) using the static closed chamber method (Hutchinson and Livingston, 1993; Hutchinson and Mosier, 1981). Custom-made gas flux chambers were designed and constructed based on criteria described in the GRACEnet protocol (Baker et al., 2003; Parkin and Kaspar, 2006) to accommodate nursery containers rather than field plot studies. A structural base consisting of polyvinyl chloride (PVC) cylinders $(25.4 \mathrm{~cm}$

Table 2. Cumulative trace gas $\left(\mathrm{CO}_{2} \mathrm{CH}_{4}\right.$, and $\left.\mathrm{N}_{2} \mathrm{O}\right)$ efflux from container media during container-grown plant production using three different fertilization placements. ${ }^{\mathrm{z}}$

\begin{tabular}{lccr}
\hline & \multicolumn{3}{c}{ Cumulative efflux } \\
\cline { 2 - 4 } Fertilizer placement ${ }^{\mathrm{y}}$ & $\mathrm{CO}_{2}-\mathrm{C}(\mathrm{mg})$ & $\mathrm{CH}_{4}(\mu \mathrm{g})$ & $\mathrm{N}_{2} \mathrm{O}-\mathrm{N}(\mu \mathrm{g})$ \\
\hline Dibble & $370.85 \mathrm{~b}^{\mathrm{x}}$ & $25.62 \mathrm{a}$ & $629.25 \mathrm{~b}$ \\
Incorporated & $384.67 \mathrm{~b}$ & $15.94 \mathrm{a}$ & $2434.83 \mathrm{a}$ \\
Topdressed & $501.19 \mathrm{a}$ & $84.28 \mathrm{a}$ & $789.74 \mathrm{~b}$ \\
Non-fertilized & $266.49 \mathrm{c}$ & $36.52 \mathrm{a}$ & $14.45 \mathrm{c}$ \\
\hline
\end{tabular}

${ }^{\mathrm{z}}$ Container media used was a pine bark:sand (6:1 v:v) media that had been previously amended with dolomitic limestone $\left[3.0 \mathrm{~kg} \mathrm{~m}^{-3}\left(5.0 \mathrm{lbs} / \mathrm{yd}^{3}\right)\right]$ and Micromax ${ }^{\circledR}\left[0.9 \mathrm{~kg} \cdot \mathrm{m}^{-3}\left(1.5 \mathrm{lbs} / \mathrm{yd}^{3}\right)\right]$. Cumulative efflux was calculated using the trapezoid rule $(\mathrm{n}=3)$.

${ }^{y}$ The same fertilizer rate $\left[25 \mathrm{~g}\right.$ of product (Polyon ${ }^{\circledR}$ 17-5-11) per 3-L container] was used for all placement treatments with the exception of non-fertilized pots, which received no Polyon ${ }^{\circledR}$ fertilizer.

${ }^{x}$ Means were separated using Fisher's least significant difference test in the Proc Mixed procedure $(P=$ $0.05)$.

$\mathrm{CO}_{2}=$ carbon dioxide; $\mathrm{CH}_{4}=$ methane; $\mathrm{N}_{2} \mathrm{O}=$ nitrous oxide.

i.d. $\times 38.4 \mathrm{~cm}$ tall) was sealed at the bottom. During gas measurements, the entire plantpot system was placed inside the base cylinder and a vented flux chamber $(25.4 \mathrm{~cm}$ diameter $\times 11.4 \mathrm{~cm}$ height) was placed on top of the base cylinder. Top flux chambers were constructed with PVC, covered with reflective tape, and contained a center sampling port. Gas samples were taken at 0-, 15-, 30-, and 45-min intervals after chamber closure. At each time interval, gas samples $(10 \mathrm{~mL})$ were collected with polypropylene syringes and injected into evacuated glass vials $(6 \mathrm{~mL})$ fitted with butyl rubber stoppers as described by Parkin and Kaspar (2006). Corresponding air temperature data were collected for each sampling period using Hobo Portable Temperature Data Loggers (Model H08-032-08 with Solar Shield; Onset Computer Corp., Bourne, MA). Although container media moisture levels were not measured during this study, gas samples were collected in the morning before any irrigation event (with the exception of uncontrollable weather events) allowing container moisture levels to equilibrate before sampling.

Gas samples were analyzed using a gas chromatograph (Shimadzu GC-2014, Columbia, $\mathrm{MD})$ equipped with three detectors: thermal conductivity detector for $\mathrm{CO}_{2}$, electrical conductivity detector for $\mathrm{N}_{2} \mathrm{O}$, and flame ionization detector for $\mathrm{CH}_{4}$. Gas concentrations were determined by comparison with standard curves developed using gas standards obtained from Air Liquide America Specialty Gases LLC (Plumsteadville, PA). Gas fluxes were calculated from the rate of change in concentration of trace gas $\left(\mathrm{CO}_{2}\right.$, $\mathrm{N}_{2} \mathrm{O}$, or $\mathrm{CH}_{4}$ ) in the chamber headspace during the time intervals, whereas chambers were closed $(0,15,30$, and $45 \mathrm{~min})$ as described by Parkin and Venterea (2010). Calculations in this study were used to express data as milligrams $\mathrm{CO}_{2}-\mathrm{C}$, micrograms $\mathrm{CH}_{4}-\mathrm{C}$, and micrograms $\mathrm{N}_{2} \mathrm{O}-\mathrm{N}$ trace gas per day. Estimates of cumulative efflux were calculated from gas efflux at each sampling date integrated over time using a basic numerical integration technique (i.e., trapezoidal rule; Yeh, 1991).

On study completion, all plants were measured and destructively harvested as described previously for determination of $\mathrm{C}$ accumulation in plant biomass. Trace gas data were analyzed on each individual sampling date (data not shown), across all dates, and cumulatively. All trace gas and growth data were analyzed using the Proc Mixed procedure in SAS (SAS ${ }^{\circledR}$ Institute Version 9.1, Cary, NC). 
Means were separated using Fisher's least significance difference test in the Proc Mixed procedure. In all cases, differences were considered significant at $P \leq 0.05$.

\section{Results}

Average daily trace gas emissions from containers with plants indicated that $\mathrm{CO}_{2}-\mathrm{C}$ efflux was lower in the dibble treatment (160.16 mg CO $2-\mathrm{C}$ ) when compared with incorporated or topdressed treatments (193.59 and $192.58 \mathrm{mg} \mathrm{CO}_{2}-\mathrm{C}$, respectively); all fertilized treatments had higher values than the non-fertilized containers (Fig. 1). The incorporated treatment had higher $\mathrm{CO}_{2}-\mathrm{C}$ efflux than any other treatment on 10 of the 29 sampling dates, whereas the topdressed treatment was highest on six dates (data not shown). Efflux from the dibble treatment was lower than incorporated or topdressed on nine dates and had similar values to the non-fertilized treatment on four dates (data not shown); this pattern was also observed for cumulative $\mathrm{CO}_{2}-\mathrm{C}$ losses (Table 1). Average daily efflux from media-only containers showed dibble and incorporated treatments had lower $\mathrm{CO}_{2}$-C efflux (86.73 and $87.84 \mathrm{mg}$ $\mathrm{CO}_{2}-\mathrm{C}$, respectively) than the topdressed treatment (118.96 $\mathrm{mg} \mathrm{CO}_{2}-\mathrm{C}$ ) (Fig. 2); this pattern was also seen for cumulative efflux (Table 2).

Average $\mathrm{N}_{2} \mathrm{O}$ efflux (with plants) was highest in the incorporated treatment (489.02 $\mu \mathrm{g} \mathrm{N}_{2} \mathrm{O}-\mathrm{N}$ ) with no differences observed between dibble and topdressed treatments (156.82 and $148.96 \mu \mathrm{g} \mathrm{N}_{2} \mathrm{O}-\mathrm{N}$, respectively; Fig. 3); all placement treatments had significantly higher $\mathrm{N}_{2} \mathrm{O}-\mathrm{N}$ efflux than the nonfertilized containers. Cumulative $\mathrm{N}_{2} \mathrm{O}$ efflux also illustrated that more $\mathrm{N}_{2} \mathrm{O}-\mathrm{N}$ was lost from the incorporated treatment (Table 1). On 15 of the 29 dates, the incorporated treatment had a higher $\mathrm{N}_{2} \mathrm{O}-\mathrm{N}$ efflux than any other treatment (data not shown). Efflux from the media-only containers followed similar trends (Fig. 4; Table 2) except that a much higher efflux was observed when no plants were present.

Methane efflux patterns were inconsistent (both with and without plants) but remained relatively low in all treatments for most of the study with no differences observed in daily averages among treatments (Figs. 5 and 6). Cumulative $\mathrm{CH}_{4}$ efflux (with plants) showed the lowest value in the dibble treatment and the highest value in the non-fertilized treatment with other treatments showing no significant difference (Table 1). No differences were observed in cumulative $\mathrm{CH}_{4}$ efflux among media-only containers (Table 2 ). On many sampling dates, it is likely $\mathrm{CH}_{4}$ efflux values were close to or below the detection limits of the gas chromatograph.

Gumpo azalea root and shoot dry weights did not differ among fertilizer placements at

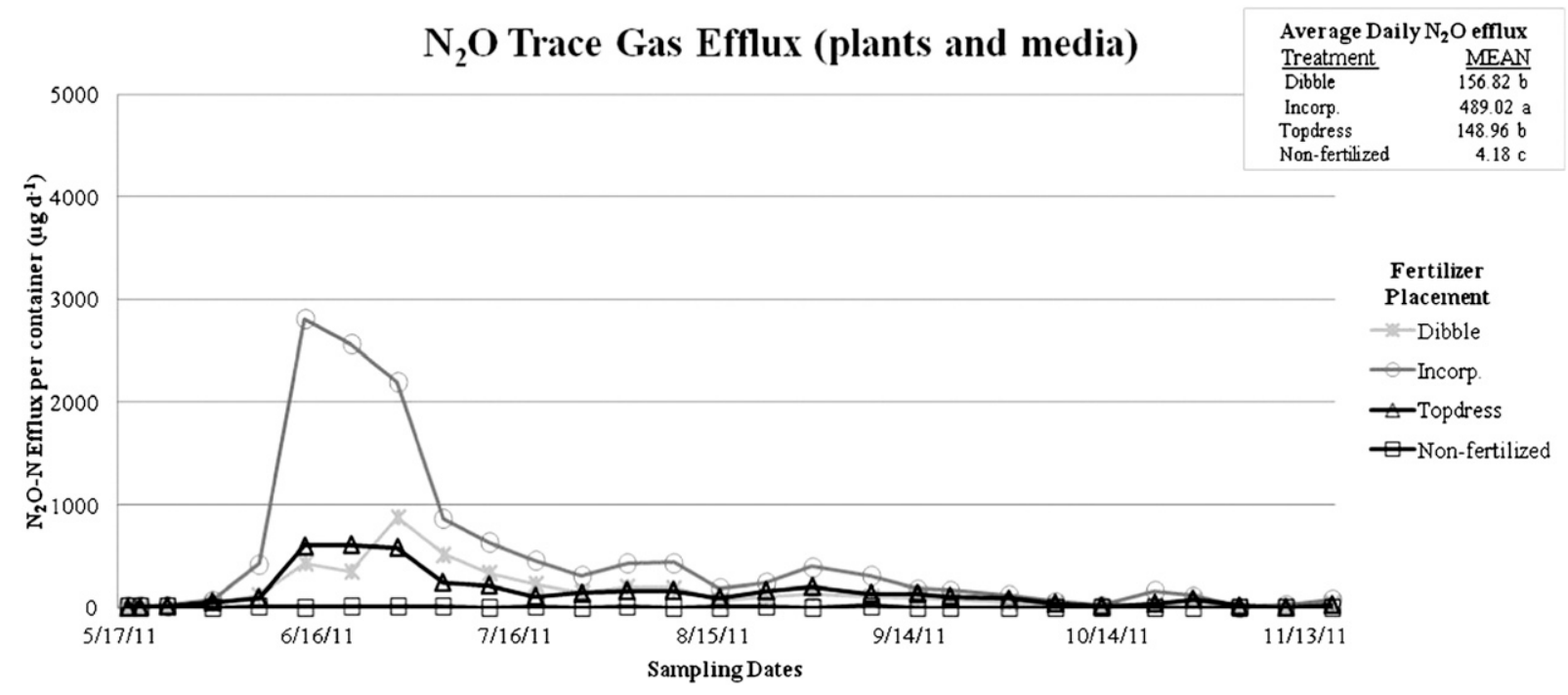

Fig. 3. $\mathrm{N}_{2} \mathrm{O}-\mathrm{N}$ efflux $\left(\mu \mathrm{g} \cdot \mathrm{d}^{-1}\right)$ for gumpo azaleas grown with three different fertilizer placements for 6 months (17 May to 17 Nov. 2011). The inset shows average daily efflux (means followed by the same letter are not significantly different from each other, $P \leq 0.05$ ).

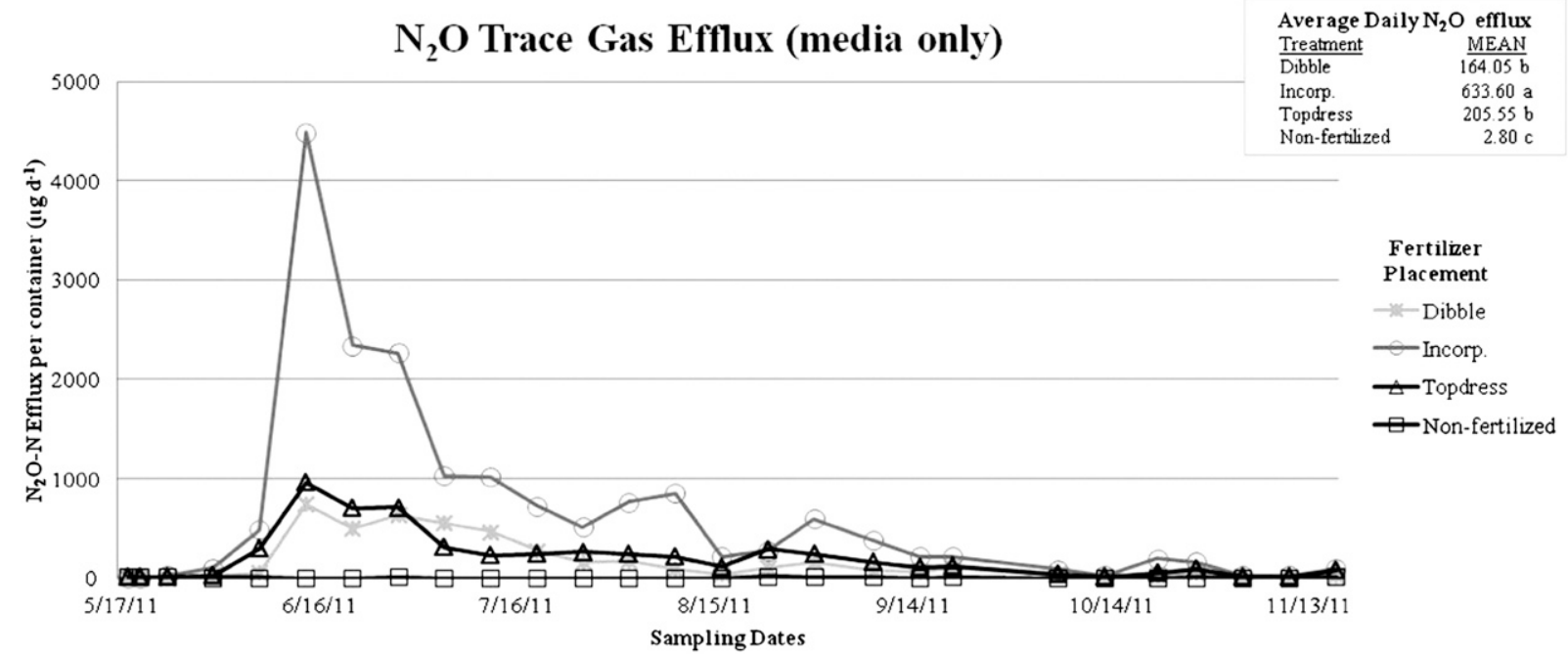

Fig. 4. $\mathrm{N}_{2} \mathrm{O}-\mathrm{N}$ efflux $\left(\mu \mathrm{g} \cdot \mathrm{d}^{-1}\right)$ from container media with three different fertilizer placements for 6 months (17 May to 17 Nov. 2011). The inset shows average daily efflux (means followed by the same letter are not significantly different from each other, $P \leq 0.05$ ). 


\section{$\mathrm{CH}_{4}$ Trace Gas Efflux (plants and media)}

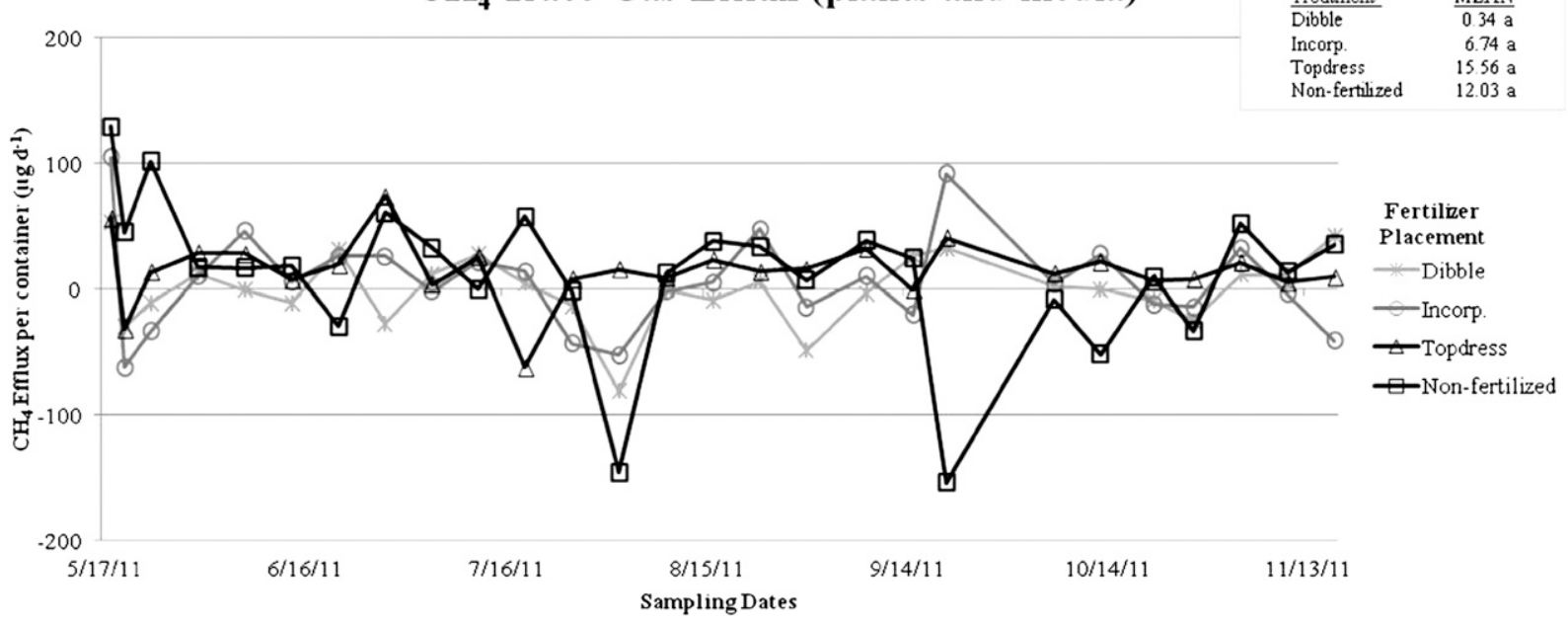

Fig. 5. $\mathrm{CH}_{4}$ efflux $\left(\mu \mathrm{g} \cdot \mathrm{d}^{-1}\right)$ from container media with three different fertilizer placements for 6 months (17 May to 17 Nov. 2011). The inset shows average daily efflux (means followed by the same letter are not significantly different from each other, $P \leq 0.05$ ).

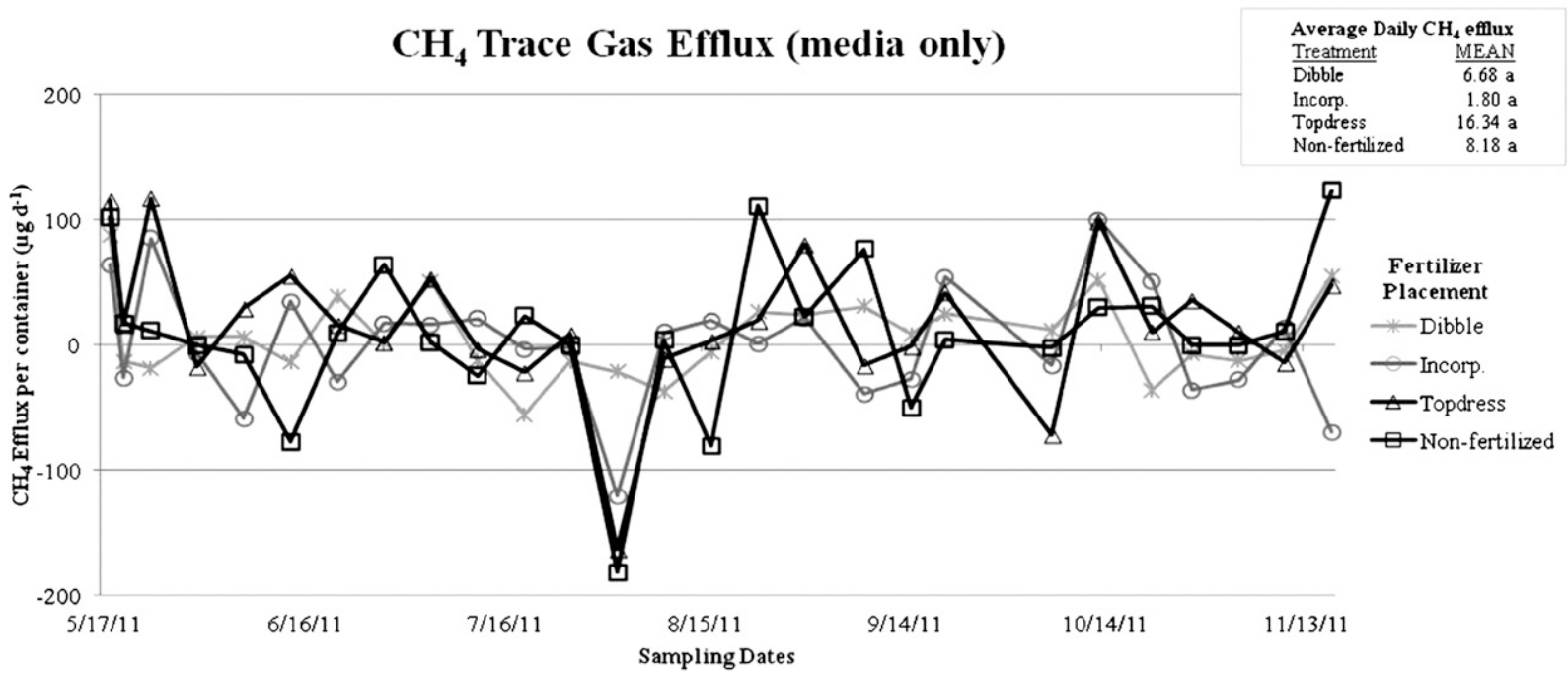

Fig. 6. $\mathrm{CH}_{4}$ efflux $\left(\mu \mathrm{g} \cdot \mathrm{d}^{-1}\right)$ for gumpo azaleas grown with three different fertilizer placements for 6 months (17 May to 17 Nov. 2011). The inset shows average daily efflux (means followed by the same letter are not significantly different from each other, $P \leq 0.05$ ).

termination of the study; all were higher than the non-fertilized treatment (Table 3). Shoot $\mathrm{C}$ followed this same pattern. However, root $\mathrm{C}$ was lowest in the topdressed treatment and highest in the non-fertilized treatment. Shoot $\mathrm{N}$ was higher in all treatments compared with the non-fertilized treatment and was higher in the incorporated treatment than the other placements; root $\mathrm{N}$ followed this same pattern.

\section{Discussion}

Lower $\mathrm{CO}_{2}-\mathrm{C}$ efflux in the media-only non-fertilized treatment must be the result of lower heterotrophic respiration, likely attributable to $\mathrm{N}$ limitation in the microbial populations. Lower efflux in the non-fertilized treatment (with plants) was likely the result of a combination of lower heterotrophic respiration and lower autotrophic respiration resulting from smaller plant size. Higher $\mathrm{CO}_{2}-\mathrm{C}$ efflux for the topdressed treatment (media only)

Table 3. Biomass, carbon, and nitrogen content of white gumpo azalea shoots and roots ${ }^{\mathrm{z}}$ after container production using three different fertilization placements.

\begin{tabular}{|c|c|c|c|c|c|c|}
\hline \multirow{2}{*}{$\begin{array}{l}\text { Fertilizer } \\
\text { placement }^{\mathrm{y}}\end{array}$} & \multicolumn{3}{|c|}{ Shoots } & \multicolumn{3}{|c|}{ Roots } \\
\hline & Dry wt $(\mathrm{g})$ & Carbon (\%) & Nitrogen (\%) & Dry wt (g) & Carbon (\%) & Nitrogen (\%) \\
\hline Dibble & $21.5 \mathrm{a}^{\mathrm{x}}$ & $45.4 \mathrm{~b}$ & $1.6 \mathrm{~b}$ & $10.1 \mathrm{a}$ & $46.4 \mathrm{ab}$ & $0.9 \mathrm{~b}$ \\
\hline Incorporated & $27.1 \mathrm{a}$ & $45.3 \mathrm{~b}$ & $1.7 \mathrm{a}$ & $11.6 \mathrm{a}$ & $47.2 \mathrm{ab}$ & $1.2 \mathrm{a}$ \\
\hline Topdressed & $24.6 \mathrm{a}$ & $45.4 \mathrm{~b}$ & $1.6 \mathrm{~b}$ & $11.0 \mathrm{a}$ & $46.0 \mathrm{~b}$ & $1.1 \mathrm{~b}$ \\
\hline Non-fertilized & $0.9 \mathrm{~b}$ & $46.7 \mathrm{a}$ & $0.3 \mathrm{c}$ & $1.2 \mathrm{~b}$ & $47.5 \mathrm{a}$ & $0.3 \mathrm{c}$ \\
\hline
\end{tabular}

${ }^{2}$ Azalea shoots show the carbon and nitrogen content of all aboveground plant material (leaves, stems, branches). Azalea roots show the carbon and nitrogen content of belowground plant material (roots only). ${ }^{y}$ The same fertilizer rate $\left[25 \mathrm{~g}\right.$ of product (Polyon ${ }^{\circledR} 17-5-11$ ) per $3 \mathrm{~L}$ container] was used for all placement treatments with the exception of non-fertilized pots, which received no Polyon $\AA$ fertilizer. Media in all treatments was amended with dolomitic limestone $\left[3.0 \mathrm{~kg} \cdot \mathrm{m}^{-3}\left(5.0 \mathrm{lbs} / \mathrm{yd}^{3}\right)\right]$ and Micromax ${ }^{\circledR}\left[0.9 \mathrm{~kg} \cdot \mathrm{m}^{-3}\right.$ $\left.\left(1.5 \mathrm{lbs} / \mathrm{yd}^{3}\right)\right]$.

y Means were separated using Fisher's least significant difference test in the Proc Mixed procedure $(P \leq$ $0.05)$.

compared with the other treatments may be the result of stimulation of the microbial populations near the media surface where the topdressed fertilizer was placed. Lower efflux for the dibble treatment (with plants) compared with the other placements may be the result of patterns of root growth impacting autotrophic respiration. Altland et al. (2004) has shown that dibble placement of fertilizer can slightly reduce root growth of container-grown crops. 
Furthermore, growth index taken approximately halfway through the study (data not shown) indicated plants receiving dibble treatment were slightly smaller. Other studies using nursery crops have reported variable growth responses to fertilizer placement. Meadows and Fuller (1983) showed that dibble application of a controlled-release fertilizer resulted in better growth of four azalea cultivars and two holly cultivars than when fertilizers were incorporated. Meadows and Fuller (1984) showed different results in a later study in which surface application or topdressing resulted in better growth of three azalea cultivars than dibble application. Cobb and Holt (1984) also showed that topdressing with a sulfur-coated urea fertilizer increased growth of woody nursery crops when compared with dibbling or incorporating fertilizers. Our results demonstrate that plant growth was similar among all fertilization treatments at the conclusion of the study, but dibble fertilizer placement reduced $\mathrm{CO}_{2}-$ $\mathrm{C}$ losses in azalea container production.

Nitrous oxide emissions were generally higher in media-only containers. When no plants were present to use $\mathrm{N}$ before it is emitted as $\mathrm{N}_{2} \mathrm{O}$, a much higher $\mathrm{N}_{2} \mathrm{O}$ flux can be expected (Wagner-Riddle et al., 1994). Nitrous oxide emissions were consistently higher when fertilizer was incorporated. There are two possible explanations as to why efflux from the incorporation treatment was much higher than that observed from dibble or topdressed treatments. Because fertilizer was placed closer to roots in the dibble treatment, the plant was likely able to use the fertilizer more efficiently, especially at earlier dates when plant roots were small and localized, which has been shown to reduce $\mathrm{N}_{2} \mathrm{O}$ emissions (CAST, 2004); however, dibble placement did not appear to increase plant growth or $\mathrm{N}$ concentration when compared with other fertilization placements. Second, the controlled-release fertilizer used has a release rate that is highly dependent on temperature and moisture. The incorporation treatment had much greater contact with media (and subsequently moisture) than the topdressed treatment and likely had a faster release rate. A faster release rate from the incorporated treatment also likely caused the higher $\mathrm{N}$ in azalea shoots and roots; however, this higher $\mathrm{N}$ did not result in plant growth differences (Table 3 ). In fact, all fertilized plants had $\mathrm{N}$ concentrations within the recommended sufficiency range (Mills and Jones, 1996). Previous investigations examining the effects of fertilizer placement on GHG emissions from agriculture have shown inconsistent results (Millar et al., 2010). For example, Liu et al. (2006) showed deep (10 to $15 \mathrm{~cm}) \mathrm{N}$ placement resulted in a reduction of up to $70 \%$ in $\mathrm{N}_{2} \mathrm{O}$ loss when compared with a shallow placement $(5 \mathrm{~cm})$, whereas Drury et al. (2008) showed $\mathrm{N}_{2} \mathrm{O}$ flux increased $26 \%$ with deep injection $(10 \mathrm{~cm})$ compared with a shallow $(2 \mathrm{~cm})$ injection. Based on our results (using a controlledrelease product), it appears that incorporating fertilizer significantly increased $\mathrm{N}_{2} \mathrm{O}$ efflux compared with the other two methods.
Although $\mathrm{CH}_{4}$ was produced at times in this study, efflux was generally low and differences among treatments were only observed when plants were included. Previous work has shown that $\mathrm{CH}_{4}$ fluxes from dry or well-drained soils are generally small compared with saturated soils (Bharati et al., 2001; Robertson et al., 2000). Because the media used in this study was well drained, the anaerobic conditions needed for methane production were likely infrequent. Methane is generally thought to contribute significantly to the atmospheric pool from agriculture through enteric fermentation in ruminant animals, rice production, and manure handling (Cole et al., 1997). Based on results from this study, $\mathrm{CH}_{4}$ efflux does not appear to have a significant effect on total trace gas emissions from container-grown nursery crops.

Results from this study indicate that dibbling fertilizer may reduce total trace gas emissions $\left(\mathrm{CO}_{2}, \mathrm{CH}_{4}\right.$, and $\mathrm{N}_{2} \mathrm{O}$ collectively) from container production systems. When plants were included (like in a nursery production setting), dibbling reduced $\mathrm{CO}_{2}$ emissions compared with incorporation and topdressed treatments, whereas plant growth was statistically similar at the conclusion of the study. Dibbling and topdressing also significantly reduced $\mathrm{N}_{2} \mathrm{O}$ emissions (68\% and 70\%, respectively) compared with the incorporated treatment. Although dibbling also resulted in lower $\mathrm{CH}_{4}$ emissions than topdressed treatments, the fact that $\mathrm{CH}_{4}$ efflux was low in all treatments indicates that $\mathrm{CH}_{4}$ is not a trace gas of concern from container production systems regardless of the fertilization method used. Further work is needed to determine the impact of different production variables on trace gas emissions from container plant production. However, results from this study begin to provide evidence of mitigation strategies, which can be implemented in container plant production to help growers benefit from $\mathrm{C}$ offset programs, adapt to future legislation, and improve the environmental impact from container plant production without negatively affecting crop growth.

\section{Literature Cited}

Adams, D.C. 2009. Agriculture and greenhouse gas cap-and-trade. 22 Feb. 2012. <http:// ageconsearch.umn.edu/bitstream/93679/2/Issue $\%$ 203.pdf $>$.

Altland, J.E., G.B. Fain, and K. Von Arx. 2004 Fertilizer placement and herbicide rate affect weed control and crop growth in containers. J. Environ. Hort. 22:93-99.

Baker, J., G. Doyle, G. McCarthy, A. Mosier, T. Parkin, D. Reicosky, J. Smith, and R. Venterea. 2003. GRACEnet chamber-based trace gas flux measurement protocol. Trace gas protocol development committee, 14 Mar. p. 1-18.

Bharati, K., S.R. Mohanty, V.R. Rao, and T.K. Adhya. 2001. Influence of flooded and nonflooded conditions on methane efflux from two soils planted to rice. Global Change Sci. 3:2532 .

Blanford, D. and T. Josling. 2009. Greenhouse gas reduction policies and agriculture: Implications for production incentives and international trade disciplines. 2 Feb. 2012. <http://dspace. cigilibrary.org/jspui/bitstream/123456789/28223/
1/ Greenhouse $\% 20$ gas $\% 20$ reduction $\% 20$ policies $\%$ 20and\%20agriculture.pdf?1>.

Breitenbeck, G.A. and J.M. Bremner. 1986. Effects of rate and depth of fertilizer application on emission of nitrous oxide from soil fertilized with anhydrous ammonia. Biol. Fertil. Soils 2:201-204.

Chicago Climate Exchange. 2009. General offset program provisions. 5 Nov. 2009. <http://www. chicagoclimatex.com/docs/offsets/CCX_General_ Offset_Program_Provisions_Final.pdf $>$.

Cobb, G.S. and G.A. Holt. 1984. Fertilizer application techniques for container-grown woody ornamentals. Proc. Southern Nur. Assoc. Res. Conf. 29:35-39.

Cole, C.V., J. Duxbury, J. Freney, O. Heinemeyer, K. Minami, A. Mosier, K. Paustian, N. Rosenburg, N. Sampson, D. Sauerbeck, and Q. Zhao. 1997. Global estimates of potential mitigation of greenhouse gas emissions by agriculture. Nutr. Cycl. Agroecosyst. 49:221-228.

Council for Agricultural Science and Technology. 2004. Climate change and greenhouse gas mitigation: Challenges and opportunities for agriculture. In: Paustian, K. and B. Babcock (eds.). Report 141.

Dlugokencky, E.J., R.C. Myers, P.M. Lang, K.A Masarie, A.M. Crotwell, K.W. Thoning, B.D. Hall, J.W. Elkins, and L.P. Steele. 2005. Conversion of NOAA atmospheric dry air $\mathrm{CH}_{4}$ mole fractions to a gravimetrically prepared standard scale. J. Geophys. Res. 110:18306.

Drury, C.F., X.M. Yang, W.D. Reynolds, and N.B. McLaughlin. 2008. Nitrous oxide and carbon dioxide emissions from monoculture and rotational cropping of corn, soybean and winter wheat. Can. J. Soil Sci. 88:163-174.

Engel, R., D.L. Liang, R. Wallander, and A. Bembenek. 2009. Influence of urea fertilizer placement on nitrous oxide production from a silt loam soil. J. Environ. Qual. 39:115-125.

Environmental Protection Agency. 2009. Current and near term greenhouse gas reduction incentives. 12 April 2009. <http://www.epa.gov/ climatechange/policy/neartermghgreduction. html>.

Hall, C.R., A.W. Hodges, and J.J. Haydu. 2005. Economic impacts of the green industry in the U.S. 4 June 2010. <http://www.utextension.utk. edu/hbin/greenimipact.html $>$.

Hosen, Y., H. Tsuruta, and K. Minami. 2000. Effects of depth of $\mathrm{NO}$ and $\mathrm{N}_{2} \mathrm{O}$ productions in soil on their emission rates to the atmosphere: Analysis by a simulation model. Nutr. Cycl. in Agroeco. 57:83-98.

Houghton, R.A. 2003. Revised estimates of the annual net flux of carbon to the atmosphere from changes in land use and land management. Tellus 55B:378-390.

Hutchinson, G.L. and G.P. Livingston. 1993. Use of chamber systems to measure trace gas fluxes, p. 63-78. In: Harper, L.A., A.R. Moiser, J.M. Duxbury, and D.E. Rolston (eds.). Agricultural ecosystem effects on trace gas and global climate change. ASA Spec. Publ. 55. ASA, Madison WI.

Hutchinson, G.L. and A.R. Mosier. 1981. Improved soil cover method for field measurements of nitrous oxide fluxes. Soil Sci. Soc. Amer. J. 45:311-316.

IPCC. 2007. Contribution of Working Group II to the Fourth Assessment Report of the Intergovernmental Panel on Climate Change. In: Parry, M.L., O.F. Canziani, J.P. Palutikof, P.J. van der Linden, and C.E. Hanson (eds.). Cambridge University Press, Cambridge, UK.

Johnson, D.E., T.M. Hill, G.M. Ward, K.A. Johnson, M.E. Branine, B.R. Carmean, and D.W. Lodman. 
1993. Ruminants and other animals, p. 199-299. In: Khalil, M.A.K. (ed.). Atmospheric methane: Sources, sinks, and role in global change. Springer-Verlag, New York, NY.

Johnson, J.M., A.J. Franzleubbers, S.L. Weyers, and D.C. Reicosky. 2007. Agriculture opportunities to mitigate greenhouse gas emissions. Environ. Pollut. 150:107-124.

Keeling, C.D. and T.P. Whorf. 2005. Atmospheric $\mathrm{CO}_{2}$ records from sites in the SIO air sampling network. In: Trends: A compendium of data on global change. Carbon Dioxide Information Analysis Center, Oak Ridge National Laboratory, U.S. Department of Energy, Oak Ridge, TN. <http://gcmd.nasa.gov/records/GCMD_ CDIAC_CO2_SIO.html>.

Kroeze, C. and A.R. Mosier. 2000. New estimates for emissions of nitrous oxide, p. 45-64. In: van Ham, J.E.A. (ed.). Non- $\mathrm{CO}_{2}$ greenhouse gases: Scientific understanding, control and implementation. Kluwer Academic Publishers, Dordrecht, The Netherlands.

Kroeze, C., A.R. Mosier, and L. Bouwman. 1999. Closing the global $\mathrm{N}_{2} \mathrm{O}$ budget: A retrospective analysis 1500-1994. Global Biogeochem. Cycles 13:1-8.

Leng, R.A. 1991. Improving ruminant production and reducing methane emissions from ruminants by strategic supplementation. US EPA report 400/1-91/004.

Lin, E., H. Dong, and Y. Li. 1994. Methane emissions of China: Agricultural sources and mitigation options, p. 405-410. In: van Ham, J., et al. (eds.). Non- $\mathrm{CO}_{2}$ greenhouse gases. Kluwer Academic Publishers, Dordrecht, The Netherlands.

Liu, X.J., A.R. Mosier, A.D. Halvorson, and F.S. Zhang. 2006. The impact of nitrogen placement and tillage on $\mathrm{NO}, \mathrm{N}_{2} \mathrm{O}, \mathrm{CH}_{4}$, and $\mathrm{CO}_{2}$ fluxes from a clay loam soil. Plant Soil 280:177-188.

Meadows, W.A. and D.L. Fuller. 1983. Relative effectiveness of dibble applied vs. incorporated Osmocote for container-grown woody ornamentals. Proc. Southern Nur. Assoc. Res. Conf. 28:63-66.

Meadows, W.A. and D.L. Fuller. 1984. Plant quality and leachate effluent as affected by rate and placement of Osmocote and SREF on containergrown woody ornamentals. Proc. Southern Nur. Assoc. Res. Conf. 29:75-79.

Millar, N., G.P. Robertson, P.R. Grace, R.J. Gehl, and J.P. Hoben. 2010. Nitrogen fertilizer management for nitrous oxide $\left(\mathrm{N}_{2} \mathrm{O}\right)$ mitigation in intensive corn (Maize) production: An emissions reduction protocol for US Midwest agriculture. Mitig. Adapt. Strategies Glob. Change 15:185-204.

Mills, H.A. and J.B. Jones. 1996. Plant analysis handbook II. MicroMacro Publishing, Athens, GA.

Moore, J.N. and K.V. Bruggen. 2011. Agriculture's fate under climate change: Economic and environmental imperatives for action. 12 Dec. 2011. <http:/www.cklawreview.com/wp-content/ uploads/vol86no1/MooreVanBruggen.pdf $>$.

Mosier, A., J.M. Duxbury, J.R. Freney, O. Heinemeyer, and K. Minami. 1996. Nitrous oxide emissions from agricultural fields: Assessment, measurment and mitigation. Plant Soil 181:95-108.

Mosier, A.R., J.M. Duxbury, J.R. Freney, O. Heinemeyer, K. Minami, and D.E. Johnson. 1998. Mitigating agricultural emissions of methane. Clim. Change 40:39-80.

Mosier, A.R., G.A. Peterson, and L.A. Sherrod. 2003. Mitigating net global warming potential $\left(\mathrm{CO}_{2}, \mathrm{CH}_{4}\right.$ and $\left.\mathrm{N}_{2} \mathrm{O}\right)$ in upland crop productions. Methane and Nitrous Oxide International Workshop Proc. p. 273-280.

National Farmers Union. 2009. Carbon credit program. 5 Nov. 2009. <http://nfu.org/issues/ environment/carbon-credits $>$.

Oenema, O., G. Vethof, and P. Kuikman. 2001. Technical and policy aspects of strategies to decrease greenhouse gas emissions from agriculture. Nutr. Cycl. Agroecosyst. 60:301315.

Parkin, T.B. and T.C. Kaspar. 2006. Nitrous oxide emissions from corn-soybean systems in the Midwest. J. Environ. Qual. 35:1496-1506.

Parkin, T.B. and R.T. Venterea. 2010. Sampling protocols. Chamber-based trace gas flux measurements, p. 31-39. In: Follet, R.F. (ed.). Sampling protocols. 6 Aug. $2011<\mathrm{http}$ //www.ars. usda.gov/SP2UserFiles/program/212/chapter $\% 203 . \% 20$ gracenet $\% 20$ Trace $\% 20$ Gas $\% 20$ Sampling\%20protocols.pdf $>$.

Paustian, K., O. Andren, H.H. Janzen, R. Lal, P. Smith, G. Tian, H. Tiessen, M. Van Noordwijk, and P.L. Woomer. 1997. Agricultural soils as a sink to mitigate carbon dioxide emissions. Soil Use Mgt. 13:230-244.

Paustian, K., J. Six, E.T. Elliot, and H.W. Hunt. 2000. Management options for reducing carbon dioxide emissions from agricultural soils. Biogeochem. J. 48:147-163.

Prasertsak, P., J.R. Freney, O.T. Denmead, P.G. Saffigna, B.G. Prove, and J.R. Reghenzani. 2002. Effect of fertilizer placement on nitrogen loss from sugarcane in tropical Queensland. Nutr. Cycl. Agroecosyst. 62:229-239.

Prinn, R.G., R.F. Weiss, P.J. Fraser, P.G. Simmonds, D.M. Cunnold, F.N. Alyea, S. O'Doherty, P. Salameh, B.R. Miller, J. Huang, R.H.J. Wang, D.E. Hartley, C. Harth, L.P. Steele, G. Sturrock, P.M. Midgely, and A. McCulloch. 2000. A history of chemically and radiatively important gases in air deduced from ALE/GAGE/AGAGE. J. Geophys. Res. 105:17751-17792.

Reicosky, D.C., D.W. Reeves, S.A. Prior, G.B. Runion, H.H. Rogers, and R.L. Raper. 1999. Effects of residue management and controlled traffic on carbon dioxide and water loss. Soil Tillage Res. 52:153-165.

Robertson, G.P., E.A. Paul, and R.R. Harwood. 2000. Greenhouse gases in intensive agriculture: Contributions of individual gases to the radiative forcing of the atmosphere. Science 289:1922-1925.

Safley, L.M., M.E. Casada, J.W. Woodbury, and K.F. Roos. 1992. Global methane emissions from livestock and poultry manure. USEPA report 400/1-91/048. Office of Air and Radiation, Washington, DC.
Schmidt, C.W. 2009. Carbon offsets. Environ. Health Perspect. 117:63-68.

Smith, K.A., L.P. McTaggart, and H. Tsuruta. 1997. Emissions of $\mathrm{N} 2 \mathrm{O}$ and $\mathrm{NO}$ associated with nitrogen fertilization in intensive agriculture, and the potential for mitigation. Soil Use Mgt. 13:296-304.

Smith, P., D. Martino, Z. Cai, D. Gwary, H. Janzen, P. Kumar, B. McCarl, S. Ogle, F. O’Mara, C. Rice, B. Scholes, O. Sirotenko, M. Howden, T. McAllister, G. Pan, V. Romanenkov, U. Schneider, S. Towprayoon, M. Wattenbach, and J. Smith. 2008. Greenhouse gas mitigation in agriculture. Phil. Trans. R. Soc. B. 363: 789-813.

Smith, P., D.S. Powlson, M.J. Glendining, and J.U. Smith. 1998. Preliminary estimates of the potential for carbon mitigation in European soils through no-till farming. Glob. Change Biol. 4: 679-685.

Snyder, C.S., T.W. Bruulsema, and T.L. Jensen. 2007. Best management practices to minimize greenhouse gas emissions associated with fertilizer use. Better Crops 91:16-18.

Snyder, C.S., T.W. Bruulsema, and T.L. Jensen. 2009. Review of greenhouse gas emissions from crop production systems and fertilizer management effects. Agr. Ecosyst. Environ. 13: 247-266.

Stefanson, R.C. 1976. Denitrification from nitrogen fertilizer placed at various depths in the soil-plant system. Soil Sci. 121:353-363.

USDA. 2008. U.S. Agriculture and Forestry greenhouse gas inventory: 1990-2005. 29 Mar. 2009. $<$ http://www.usda.gov/oce/global_change/AFGG_ Inventory/USDA_GH G_Inventory.pdf $>$.

Wagner-Riddle, C., G.W. Thurtell, E.G. Beauchamp, G.E. Kidd, and R. Sweetman. 1994. Nitrous oxide emissions from agricultural fields. Annual Report. Department of Land Resource Science, University of Guelph, Guelph, Ontario, Canada.

Watson, R.T., I.R. Noble, B. Bolin, N.H. Ravindranath, D.J. Verardo, and D.J. Dokken. 2000. Land use, land-use change, and forestry, 2000. Special report of the Intergovernmental Panel on Climate Change, Cambridge University Press, Cambridge, UK.

Weier, K.L., J.W. Doran, J.F. Power, and D.T. Walters. 1993. Denitrification and the dinitrogen/ nitrous oxide ratio as affected by soil water, available carbon and nitrate. Soil Sci. Soc. Amer. J. 57:66-72.

Yamulki, S. and S.C. Jarvis. 2002. Short-term effects of tillage and compaction on nitrous oxide, nitric oxide, nitrogen dioxide, methane and carbon dioxide fluxes from grassland. Biol. Fertil. Soils 36:224-231.

Yeh, S.T. 1991. Using trapezoidal rule for the area under a curve calculation. 6 May 2012. <http:// www2.sas.com/proceedings/sugi27/p229-27.pdf>.

Youngdahl, L.J., M.S. Lupin, and E.T. Cranswell. 1986. New developments in nitrogen fertilizers for rice. Fert. Res. 9:149-160. 